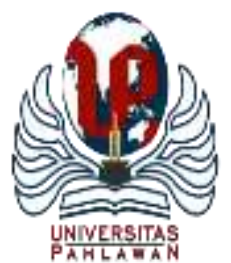

Edukatif : Jurnal Ilmu Pendidikan Volume 4 Nomor 1 Tahun 2022 Halm 1536 - 1543

EDUKATIF: JURNAL ILMU PENDIDIKAN

Research \& Learning in Education

https://edukatif.org/index.php/edukatif/index

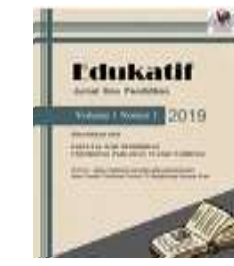

\title{
Analisa Kebutuhan dalam Pengembangan Bahan Ajar Digital Bahasa Inggris Pariwisata di Sekolah Menengah Kejuruan
}

\author{
Pande Agus Adiwijaya ${ }^{1 凶}$, Luh Made Dwi Wedayanthi ${ }^{2}$ \\ ITP Markandeya Bali, Indonesia ${ }^{1,2}$ \\ E-mail : adiwijayapande@gmail.com ${ }^{1}, \underline{w e d a w i d 06 @ g m a i l . c o m ~}^{2}$
}

\begin{abstract}
Abstrak
Penelitian ini bertujuan untuk menganalisis kebutuhan guru dan siswa SMK di Bangli terkait materi pembelajaran digital. Ini merupakan bagian dari studi Penelitian dan Pengembangan yang bertujuan untuk mengembangkan materi pembelajaran digital Bahasa Inggris untuk Pariwisata di Sekolah Menengah Kejuruan di Bangli. Penelitian ini merupakan penelitian kualitatif dengan metode analisis deskriptif. Instrumen yang digunakan adalah lembar observasi, angket dan wawancara. Subyek penelitian ini adalah guru dan mahasiswa program studi pariwisata di Kabupaten Bangli. Berdasarkan analisis ditemukan bahwa terdapat 32 kompetensi dasar yang harus dikuasai oleh semua siswa dalam 3 (tiga) tahun studi di SMK, sehingga materi pembelajaran digital harus dikembangkan berdasarkan kompetensi dasar tersebut. Kompetensi dasar tersebut diajarkan di 3 (tiga) program studi, yaitu Traveling, Hoteliers, dan Culinary. Selain itu, pengembangan materi pembelajaran digital harus sesuai dengan kebutuhan guru dan siswa seperti 1) mudah diakses, 2) menarik secara visual, 3) bahasanya mudah dipahami, 4) mungkin dalam dwibahasa (Inggris dan Indonesia). , dan 5) memenuhi kriteria pengembangan materi pembelajaran digital untuk TEFL menurut Tomlinson (1998).
\end{abstract}

Kata Kunci: Bahasa Inggris untuk Pariwisata, Analisa kebutuhan, bahan ajar digital, SMK, penelitian pengembangan.

\begin{abstract}
This study aimed at analyzing the needs of the teachers and students of Vocational High School in Bangli related to digital learning material. This is a part of Research and Development study which aiming at developing digital learning material for English for Tourism in Vocational High School in Bangli. This is a qualitative study with descriptive analysis method. The instruments were observation sheet, questionnaire and interview. The subjects of this study were teacher and students of tourism study program in Bangli Regency. Based on the analysis it was found that there were 32 basic competencies that should mastered by all students within 3 (three) years of study in Vocational High School, so the digital learning material should be developed based on these basic competencies. These basic competencies were taught in 3 (three) study programs, namely Traveling, Hoteliers, and Culinary. Besides that, the development of digital learning material should be in line with teacher and students' needs such as 1) easy to access, 2) visually interesting, 3) the language is easily understood, 4) possibly in bilingual (English and Indonesian), and 5) fulfilling the criteria of developing digital learning material for TEFL by Tomlinson (1998).
\end{abstract}

Keywords: English for Tourism, needs analysis, digital learning material, Vocational High School, Research and Development.

Copyright (c) 2022 Pande Agus Adiwijaya, Luh Made Dwi Wedayanthi

$\triangle$ Corresponding author

Email : adiwijayapande@gmail.com

DOI : https://doi.org/10.31004/edukatif.v4i1.1704 
1537 Analisa Kebutuhan dalam Pengembangan Bahan Ajar Digital Bahasa Inggris Pariwisata di Sekolah Menengah Kejuruan - Pande Agus Adiwijaya, Luh Made Dwi Wedayanthi

DOI: https://doi.org/10.31004/edukatif.v4i1.1704

\section{PENDAHULUAN}

Pandemi Covid-19 telah membuka mata dunia pendidikan Indonesia secara luas bahwa, pembelajaran daring adalah salah satu wajah masa depan pendidikan di dunia. Banyak pemangku kebijakan, guru, siswa dan orang tua siswa berjibaku untuk belajar menggunakan fasilitas pembelajaran daring. Hal yang sama juga dihadapi oleh para guru SMK di Kabupaten Bangli. Banyak diantara mereka yang bersusah payah untuk membuat materi pembelajaran digital. Yang lebih menyulitkan dialami oleh para guru yang tidak biasa menyiapkan materi secara terstruktur. Guru-guru yang hanya megajar dengan mengandalkan modelling dan materi lepas harus bisa membuat materi yang terstruktur selama 1 semester dan bahkan harus dibuat dalam bentuk digital.

Permasalahan ini tentunya menjadi penghalang bagi siswa yang harus belajar mandiri dirumah. Mereka tidak mendapatkan materi yang terstruktur sehingga mereka susah dalam memahami ataupun mempraktekkan keterampilan mereka. Pembelajaran Bahasa Inggris untuk Pariwisata sebagai salah satu mata pelajaran penting dalam mencetak tenaga kerja terampil dan berdaya saing tinggi di dunia Pariwisata, khususnya Bali mengalami hal yang serupa. Jika keadaan ini berlangsung terus menerus maka dikhawatirkan daya saing tenaga kerja pariwisata di Bali khususnya yang tamatan SMK akan kalah bersaing dengan tenaga kerja lain yang mahir berbahasa Inggris.

Learning material atau bahan ajar dalam pembelajaran bahasa dapat diartikan sebagai segala hal yang bisa digunakan untuk membantu guru dalam membantu siswa belajar bahasa. Bahan ajar ini bisa berupa buku teks, buku kerja, kaset, CD-room, video, fotocopy handout, koran, paragraph yang ditulis di papan; segala hal yang menyajikan atau menginformasikan tentang Bahasa yang sedang dipelajari (Tomlinson, 1998). Menurut Howard dan Major (2004) ada 6 faktor utama yang harus diperhatikan dalam mengembangkan suatu bahan ajar bagi siswa seperti 1) siswa; 2) kurikulum dan konteksnya; 3) sumber dan fasilitas; 4) tingkat percaya diri personal dan kompetensi guru; 5) kompalin hak cipta, serta 6) waktu. Dalam kaitannya dengan pengembangan Bahan Ajar untuk penguasaan Bahasa Inggris sebagai Bahasa Asing maka Tomlinson (1998) juga menjabarkan tentang prinsip-prinsip pengembangan yang harus diperhatikan.

Tentunya, pembelajaran Bahasa Inggris untuk siswa SMK berbeda dengan siswa SMA. Hal ini dikarenakan siswa SMK membutuhkan Bahasa Inggris khusus sesuai dengan bidang keterampilannya atau dikenal dengan English for Specific Purposes (ESP). Paltridge and Starfield (2013) mendefinisikan English for Specific Purposes (ESP) sebagai pembelajaran Bahasa Inggris sebagai Bahasa Kedua atau Bahasa Asing dimana tujuan peserta didik adalah mampu menggunakan Bahasa Inggris di bidang tertentu. ESP ditujukan untuk memenuhi kebutuhan khusus peserta didik terhadap penguasaan Bahasa Inggris pada bidang tertentu (Dudley-Evans \& St.John, 2005). ESP atau Bahasa Inggris untuk tujuan khusus adalah suatu pendekatan baru dalam pengajaran dan penggunaan Bahasa Inggris untuk bidang dan kajian khusus yang sesuai dengan kebutuhan bidang ilmu dan profesi pengguna Bahasa Inggris tersebut (Hamidah \& Yanuarmawan, 2019). Biasanya ESP digunakan oleh Perusahaan atau bidang pekerjaan untuk meningkatkan kemampuan Bahasa Inggris tenaga kerja mereka. Biasanya materi, pelaksanaan pembelajaran dan evaluasi disesuaikan dengan tujuan khsusus tiap perusahaan yang dibuat dalam suatu program khusus. Dalam kaitannya dengan pembelajaran Bahasa Inggris di SMK, ESP memiliki peran yang krusial karena pengajaran bahasa dengan pendekatan ESP fokus pada kondisi siswa dengan materi tertentu yang berbeda dengan pengajaran bahasa Inggris umum (General English) (Utami dkk., 2014). Sehingga nantinya, setelah lulus para siswa sudah menguasai Bahasa Inggris yang spesifik sesuai dengan bidang kerjanya masing-masing.

Untuk mengatasi masalah ini adalah dengan mengembangkan bahan ajar digital untuk mengajar Bahasa Inggris Pariwisata di SMK. Namun, dengan beragam standar yang ditetapkan oleh tiap SMK di Kabupaten Bangli, maka perlu diidentifikasi terlebih dahulu mengenai kompetensi yang perlu dikuasai. Selain itu, perlu juga dirumuskan kebutuhan guru dan siswa SMK sehingga bahan ajar yang dihasilkan nantinya sesuai dengan 
konteks pembelajaran mereka. Untuk mendapatkan deskripsi mengenai standar dan kebutuhan tersebut, maka perlu dilakukan Analisa Kebutuhan (Need Analysis). Analisa ini juga sebagai tahap awal dari pengembangan bahan ajar digital ini.

Menurut Basturkmen (2010), analisis kebutuhan atau Need Analysis adalah mengidentifikasi bahasa dan keterampilan khusus yang dibutuhkan kelompok pembelajar bahasa. Nunun Indrasari menyatakan bahwa analisis kebutuhan merupakan teknik dalam mengidentifikasi fitur dan keterampilan bahasa tertentu yang dibutuhkan pembelajar bahasa yang kemudian menjadi dasar dalam merancang suatu mata kuliah (Indrasari, 2016). Menurut Hyland dalam Paltridge dan Starfield (2013), Analisis kebutuhan mengacu pada teknik untuk mengumpulkan dan menilai informasi yang relevan dengan desain kursus: ini adalah cara untuk menetapkan bagaimana dan apa suatu kursus. Ini adalah proses yang berkelanjutan, karena kami memodifikasi pengajaran kami saat kami belajar lebih banyak tentang siswa kami, dan dengan cara ini, ini berkaitan dengan evaluasi cara untuk menetapkan keefektifan kursus. Analisis kebutuhan adalah istilah umum yang mencakup banyak aspek, yang menggabungkan tujuan dan latar belakang pelajar, kemahiran bahasa mereka, alasan mereka mengambil kursus, preferensi pengajaran dan pembelajaran mereka, dan situasi yang mereka perlukan untuk berkomunikasi. Analisis kebutuhan dapat melibatkan apa saja pelajar tahu, tidak tahu atau ingin tahu, dan dapat dikumpulkan dan dianalisis dengan berbagai cara. Menurut Nunun Indrasari (2016), ada dua perbedaan mendasar dalam analisis kebutuhan, yaitu kebutuhan sasaran (apa yang perlu dilakukan peserta didik dalam situasi sasaran) dan kebutuhan belajar (apa yang perlu dilakukan peserta didik untuk belajar).

Berdasarkan paparan di atas, penelitian dengan judul "Analisa Kebutuhan dalam Pengembangan Bahan Ajar Digital Bahasa Inggris Pariwisata di SMK" perlu untuk dilakukan. Tujuan penelitian ini adalah untuk (1) mendeskripsikan kriteria bahan ajar digital yang baik dalam pembelajaran Bahasa Inggris Pariwisata di SMK se-Kabupaten Bangli; (2) mendeskripsikan kebutuhan guru dan siswa SMK mengenai bahan ajar digital yang perlu dikembangkan dalam pembelajaran Bahasa Inggris Pariwisata di SMK.

\section{METODE PENELITIAN}

Penelitian need analysis ini adalah awal dari proses panjang pengembangan bahan ajar digital Bahasa Inggris untuk Pariwisata. Nantinya bahan ajar digital ini akan didesain sedemikian rupa hingga bisa digunakan untuk pembelajaran daring maupun luring. Diharapkan masalah proses pembelajaran seperti yang dialami saat pandemi Covid-19 dapat diatasi di masa depan. Roadmap penelitian ini dapat dilihat pada bagan berikut:

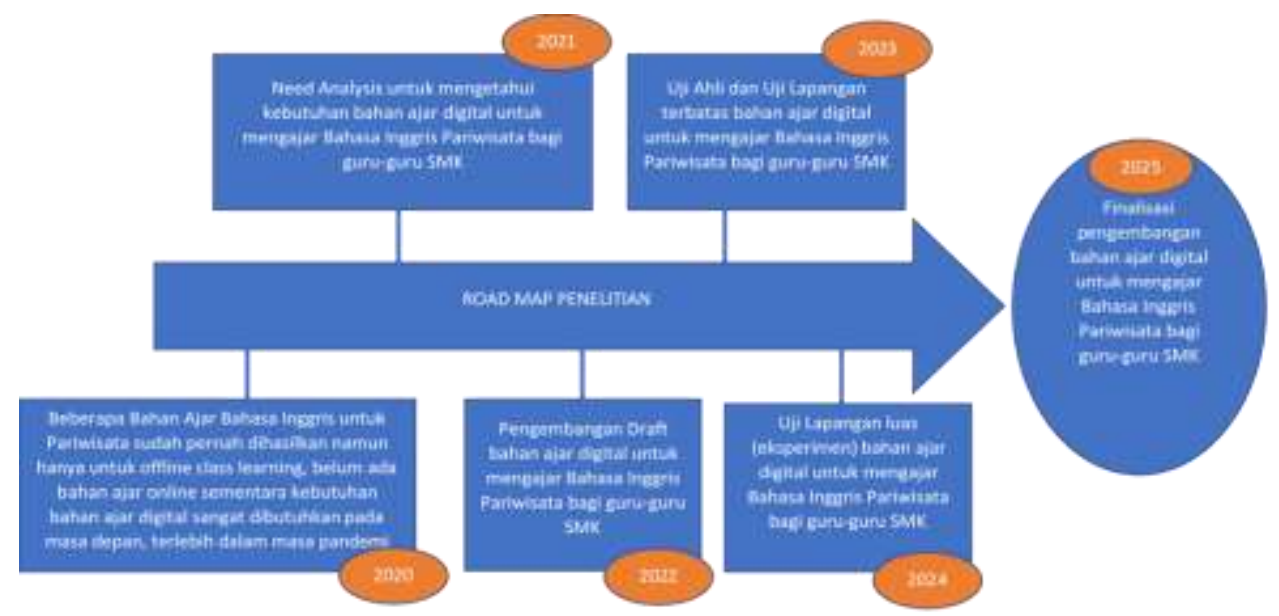

Gambar 1. Roadmap penelitian dari tahun 2021 sampai dengan tahun 2025 
Pada tahap awal ini (need analysis), peneliti fokus pada analisa bahan ajar digital seperti apa yang dibutuhkan oleh para guru dan siswa. Pada tahapan ini, penelitian ini tergolong sebagai penelitian deskriptif kualitatif yang dimulai dari persiapan penelitian, kemudian pelaksanaan penelitian, analisa penelitian, penyusunan laporan serta publikasi dan seminar hasil penelitian.

Pada tahap Need Analysis ini, rancangan penelitian yang dilakukan adalah penelitian deskriptif kualitatif. Hal ini dilakukan untuk mendapatkan data yang lebih komprehensif dan detail mengenai bahan ajar digital yang diperlukan oleh para guru dan siswa SMK dalam proses pembelajaran Bahasa Inggris untuk Pariwisata. Metode deskriptif menurut Sugiyono (2009) adalah metode yang digunakan untuk menggambarkan atau menganalisis suatu hasil penelitian tetapi tidak digunakan untuk membuat kesimpulan yang lebih luas. Sugiyono (2009) juga menjelaskan bahwa metode penelitian kualitatif atau biasa disebut metode penelitian naturalistik adalah metode penelitian yang digunakan untuk meneliti pada objek yang alamiah, dimana peneliti adalah sebagai instrumen kunci, sedangkan teknik pengumpulan data dilakukan dengan metode wawancara, analisis data bersifat induktif, dan hasil penelitian kualitatif lebih menekankan makna daripada generalisasi. Oleh karena itu dapat disimpulkan bahwa metode penelitian deskriptif kualitatif adalah suatu penelitian yang menghasilkan data secara deskriptif dimana peneliti adalah sebagai instrumen kunci, serta variabel-variabel yang bisa dijelaskan baik menggunakan angka- angka maupun kata-kata dan kesimpulannya tidak bisa digunakan untuk menyimpulkan hal yang lebih luas (Adiwijaya dkk., 2019). Penelitian ini akan dilakukan mulai disetujuinya proposal penelitian ini sampai dengan selesainya penyusunan laporan dalam bentuk laporan hasil penelitian serta publikasi artikel pada jurnal ilmiah nasional terakrediasi. Tahapan dan capaian indikator penelitian ini dapat dilihat pada bagan alir berikut ini:

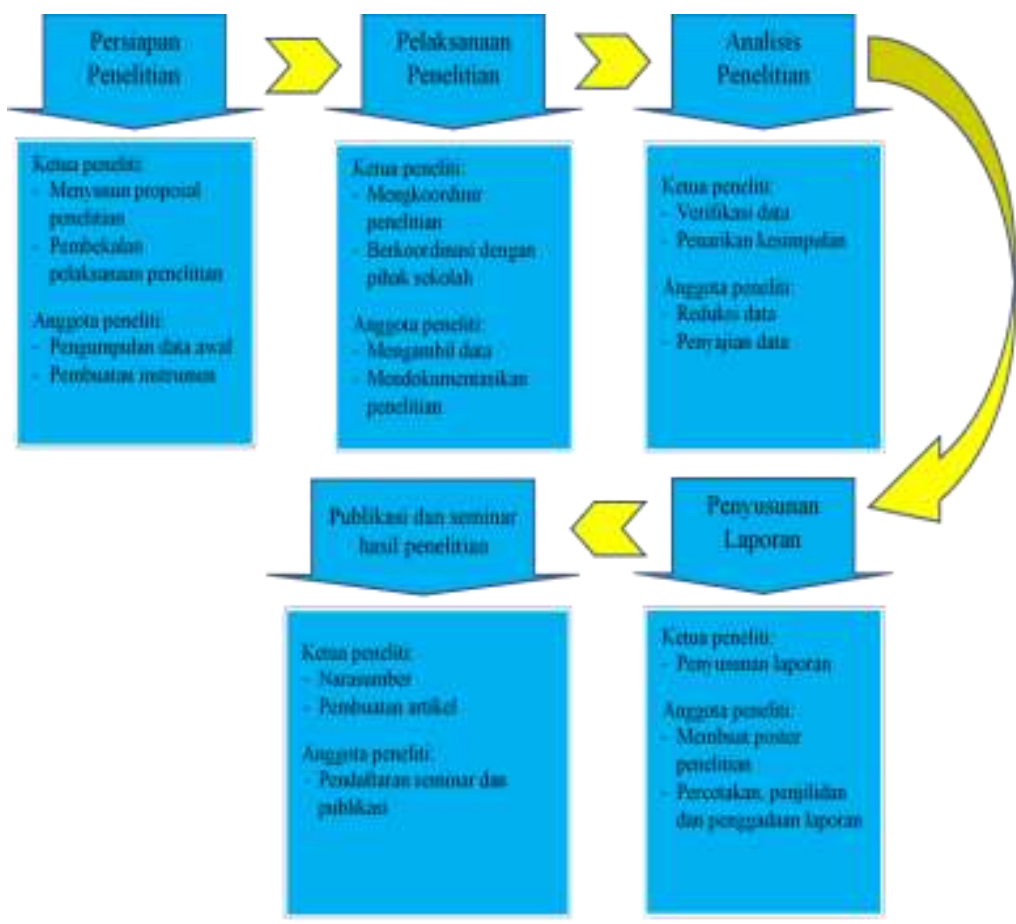

Gambar 2. Bagan Alir Penelitian

Lokasi penelitian ini adalah SMK se-Kabupaten Bangli pada tahun 2021. Subyek penelitian ini adalah seluruh guru atau instruktur yang mengajar Bahasa Inggris Pariwisata di SMK Negeri dan Swasta di Kabupaten Bangli. Obyek penelitian ini adalah kebutuhan guru-guru SMK di Kabupaten Bangli yang mengajar Bahasa Inggris Pariwisata terhadap bahan ajar digital. Instrumen pengambilan data yang digunakan adalah kuesioner, wawancara dan dokumentasi. 
Miles dan Huberman dalam Sugiyono (2009) mengemukakan bahwa analisis data dalam penelitian kualitatif dilakukan pada saat pengumpulan data berlangsung, dan setelah selesai pengumpulan data setelah selesai pengumpulan data dalam periode tertentu. Model interaktif dalam analisis data ditunjukkan pada gambar di bawah ini:

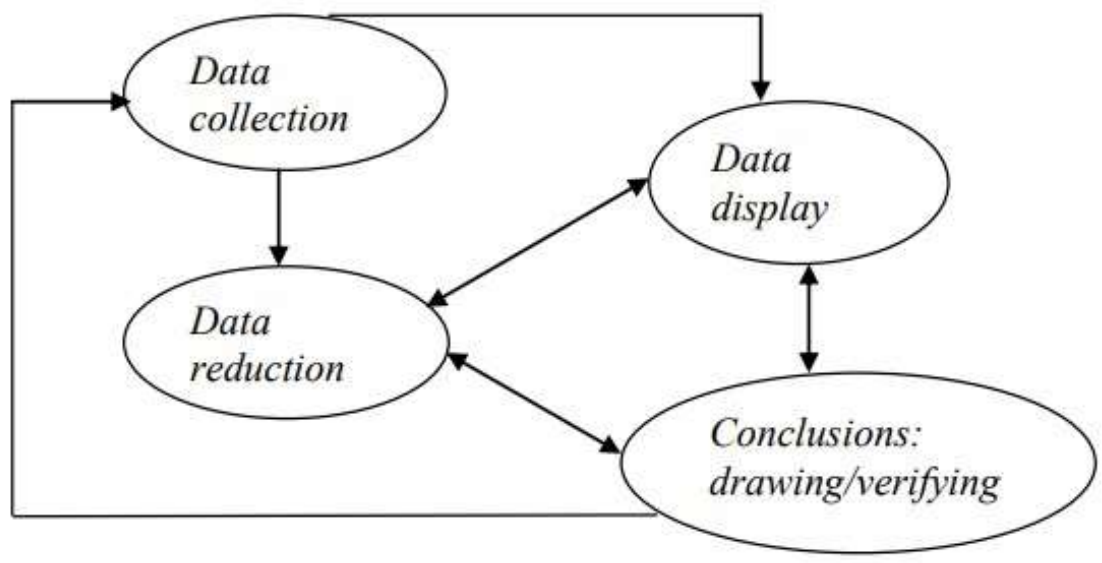

Gambar 3. Langkah-langkah analisa data menurut Miles dan Huberman (Sugiyono, 2009) berikut:

Berdasarkan Gambar 3. diatas dapat dijelaskan langkah-langkah analisa data dapat dilihat sebagai

1) Data collection (pengumpulan data). Pada tahap ini peneliti mengumpulkan data-data seperti silabus, RPP, kurikulum, kajian Pustaka tentang bahan ajar online, hasil kuesioner dari guru-guru pengampu mata pelajaran Bahasa Inggris untuk pariwisata.

2) Data Reduction (reduksi data). Pada tahap ini, peneliti akan melakukan pengelompokan data-data sebelum disortir. Data-data yang tidak bisa menjawab rumusan masalah, akan dikesampingkan. Data yang diperlukan untuk menjawab rumusan masalah kemudian dikumpulkan untuk dicari kesamaan dalam rangka pengambilan kesimpulan.

3) Data Display (penyajian data. Data-data yang sudah terkumpul dan disarikan, akan ditampilan dalam bentuk uraian singkat dan/atau tabel, grafik agar mudah untuk dipahami oleh pembaca.

4) Conclusion Drawing atau Verification (simpulan atau verifikasi). Simpulan akan diambil dari intisari data yang telah dijabarkan. Kesimpulan ini harus menjawab dari rumusan masalah yang telah ditetapkan sebelumnya.

\section{HASIL DAN PEMBAHASAN PENELITIAN}

Terdapat 10 Sekolah Menengah Kejuruan di Bangli yang memiliki program studi kepariwisataan yang tersebar di 4 Kecamatan, yaitu Kecamatan Bangli, Kecamatan Susut, Kecamatan Tembuku dan Kecamatan Kintamani. Mereka adalah SMKN 2 Bangli, SMKN 4 Bangli, SMKN 3 Kintamani, SMKN 2 Kintamani, SMKN 1 Tembuku, SMKN 1 Susut, SMK Sastra Mandala, SMK PGRI Tembuku, SMK Praja Pandawa dan SMK Aska Aska Bali Mandala. Dari semua SMK tersebut, hanya ada 3 program Studi Kepariwisataan yang dimiliki, yaitu Program Studi Usaha Perjalanan Wisata, Perhotelan, dan Tata Boga. Berdasarkan data ini, maka materi yang dibutuhkan sudah tentu Bahasa Inggris untuk Usaha Perjalanan Wisata, Perhotelan, dan Tata Boga.

Dari ketiga Program Studi tersebut, semua SMK di Bangli menggunakan/mengacu pada KI\&KD SMK/MAK yang dikeluarkan oleh Dirjen Pendidikan Dasar dan Menengah Nomor 330/D.D5/KEP/KR/2017 tanggal 9 Juni 2017. Pada Lampiran Keputusan tersebut disebutkan bahwa Kompetensi Bahasa Inggris untuk 


\section{Analisa Kebutuhan dalam Pengembangan Bahan Ajar Digital Bahasa Inggris Pariwisata di Sekolah Menengah Kejuruan - Pande Agus Adiwijaya, Luh Made Dwi Wedayanthi \\ DOI: https://doi.org/10.31004/edukatif.v4i1.1704}

jenjang SMK/MAK mencakup empat aspek kompetensi, yaitu (1) aspek kompetensi sikap spiritual, (2) sikap sosial, (3) pengetahuan, dan (4) keterampilan. Terkait dengan kebutuhan guru dan siswa SMK di Bangli, maka materi bahan ajar yang diperlukan harus mengacu pada aspek pengetahuan dan keterampilan yang terdiri dari 32 kompetensi dasar yang wajib dikuasai oleh lulusan SMK bidang pariwisata. Semua kompetensi dasar ini diajarkan selama masa studi SMK (3 Tahun/352 Jam pelajaran). Berdasarkan hal ini, maka bahan ajar digital yang dikembangkan harus mengacu pada penguasaan 32 kompetensi dasar tersebut.

Kebutuhan guru dan siswa SMK dicari dengan cara mengambil data tersebut langsung kepada para guru dan siswa yang akan menggunakan bahan ajar tersebut. Dalam hal ini adalah guru SMK yang mengajar Bahasa Inggris baik di kelas X, XI dan XII. Berdasarkan hasil wawancara yang dilakukan kepada guru dan siswa SMK, ditemukan beberapa kriteria yang perlu diperhatikan dalam pengembangan bahan ajar digital untuk Bahasa Inggris Pariwisata ini. Beberapa diantaranya adalah 1) mudah diakses, 2) menarik secara visual, 3) bahasanya mudah dimengerti, dan 4) jika bisa bahan ajar dalam dwi Bahasa (Bahasa Inggris dan Bahasa Indonesia).

Selain itu, peneliti juga menyelaraskan kebutuhan para guru dan siswa dengan kriteria yang baik dalam pengembangan sebuah bahan ajar. Dalam hal ini, peneliti melakukan kajian Pustaka dan berkesimpulan untuk menggunakan teori pengembangan Bahan Ajar untuk penguasaan Bahasa Inggris sebagai Bahasa Asing dari Tomlinson (1998). Dalam teroinya, ada beberapa prinsip pengembangan bahan ajar yang harus diperhatikan sebagai berikut:

1) Bahan ajar yang dikembangkan harus mencapai dampak kepada siswa.

2) Bahan ajar harus membantu siswa merasa terbantu.

3) Bahan ajar harus mampu membantu siswa meningkatkan rasa percaya diri mereka.

4) Bahan ajar yang dikembangkan harus berguna dan relevan dengan kebutuhan siswa.

5) Bahan ajar harus membutuhkan dan memfasilitasi investasi mandiri siswa.

6) Siswa harus siap menerima poin yang akan diajarkan.

7) Bahan ajar harus membuat siswa terbuka pada penggunaan Bahasa yang nyata.

8) Perhatian siswa harus ditarik pada fitur linguistik input.

9) Bahan ajar harus menyediakan kesempatan bagi siswa untuk menggunakan Bahasa yang dipelajari untuk mencapai tujuan komunikasi.

10) Bahan ajar harus memperhitungkan bahwa efek positif dari pengajaran yang biasanya tertunda.

11) Bahan ajar harus memperhatikan bahwa para siswa memiliki gaya belajar yang berbeda-beda.

12) Bahan ajar harus memperhatikan bahwa para siswa memiliki sikap efektif yang berbeda.

13) Bahan ajar harus memfasilitasi periode hening pada awal pembelajaran.

14) Bahan ajar seharusnya tidak terlalu menekankan pada latihan yang terkontrol.

15) Bahan ajar harus menyediakan kesempatan untuk hasil umpan balik.

Pengembangan bahan ajar Bahasa Inggris untuk Pariwisata di beberapa SMK di Bangli pernah dilakukan oleh beberapa peneliti sebelumnya seperti Widiana, Adiwijaya, \& Purnami (2020) yang mengembangkan buku ajar housekeeping bagi kelas pariwisata di SMK PGRI Tembuku. Juli Astari, Manuaba, \& Adiwijaya (2020) mengembangkan buku ajar F\&B Service di SMK PGRI Tembuku. Septia Ariani, Wedayanthi \& Manuaba (2020) mengembangkan buku ajar F\&B Product di SMK PGRI Tembuku. Ayuni, Adiwijaya, \& Manuaba (2020) juga mengembangkan buku ajar untuk kelas Front Office di SMK Swasta di Bangli. Namun, semua buku ajar yang dikembangkan belum bisa digunakan pada konteks pembelajaran online karena dikembangkan berdasarkan konteks pembelajaran tatap muka. Padahal bahan ajar untuk konteks pembelajaran online sangat dibutuhkan di era revolusi 4.0. Hal ini sudah terbukti saat pandemi Covid-19 dimana seluruh pembelajaran harus dilakukan secara online, namun bahan ajar yang tersedia masih 
1542 Analisa Kebutuhan dalam Pengembangan Bahan Ajar Digital Bahasa Inggris Pariwisata di Sekolah Menengah Kejuruan - Pande Agus Adiwijaya, Luh Made Dwi Wedayanthi

DOI: https://doi.org/10.31004/edukatif.v4i1.1704

berorientasi pembelajaran tatap muka. Sehingga, nantinya hasil pengembangan penelitian tersebut bisa diintegrasikan dengan bahan ajar baru yang berbasis digital.

\section{KESIMPULAN}

Simpulan yang dapat diambil berdasarkan hasil Analisa tersebut adalah terdapat 3 (tiga) program studi kepariwisataan yang diampu oleh SMK di Kabupaten Bangli. Program studi tersebut adalah Program Studi Usaha Perjalanan Wisata, Perhotelan, dan Tata Boga. Dari Analisa kompetensi dasar yang harus dimiliki oleh lulusan SMK Pariwisata di Bangli, ditemukan ada 32 kompetensi dasar yang wajib dikuasai oleh para siswa selama 3 tahun belajar di SMK. Semua kompetensi ini menjadi acuan dalam pengembangan bahan ajar digital kedepannya. Selain itu, pengembangan bahan ajar digital selanjutnya harus memperhatikan kebutuhan guru dan siswa dimana bahan ajar tersebut harus 1) mudah diakses, 2) menarik secara visual, 3) bahasanya mudah dimengerti, 4) jika bisa bahan ajar dalam dwi Bahasa (Bahasa Inggris dan Bahasa Indonesia), dan 5) memenuhi kriteria pengembangan Bahan Ajar untuk penguasaan Bahasa Inggris sebagai Bahasa Asing dari Tomlinson (1998).

Saran yang perlu disampaikan adalah peneliti atau peneliti lainnya harus mengembangkan bahan ajar digital tersebut berdasarkan kompetensi dasar yang telah ditetapkan. Pengembangan tersebut juga harus mengacu pada preferensi guru dan siswa agar nantinya bisa membantu mereka dalam proses pembelajaran di SMK.

\section{UCAPAN TERIMA KASIH}

Peneliti memberikan apresiasi setinggi-tingginya kepada Kemendikbudristek yang telah mendanai penelitian ini. Pelaksanaan penelitian ini berdasarkan kontrak penelitian nomor 069/E4.1/AK.04.PT/2021. Penelitian ini juga tidak lepas dari pembinaan LP3M ITP Markandeya Bali yang senantiasa menjadi mentor dan pembimbing selama pelaksanaan penelitian ini. Tidak pula peneliti haturkan rasa terima kasih kepada para guru dan siswa yang telah ikut terlibat aktif dalam penelitian ini.

\section{DAFTAR PUSTAKA}

Adiwijaya, P. A., Purnami, N. M. A., \& S Arsana, I. W. (2019). Perception And Obstacles Of College Students In Writing. Yavana Bhasha: Journal Of English Language Education, 2(2), 1. Https://Doi.Org/10.25078/Yb.V2i2.1008

Ariani, D. A. M. S., Wedayanthi, N. L. M. D., \& Manuaba, I. Bagus A. L. (2020). Developing Coursebook For Food And Beverage Products At Smks Pgri Tembuku Based On K13 In Academic Year 2020/2021. Stkip Suar Bangli.

Astari, D. A. M. J., Manuaba, I. B. A. L., \& Adiwijaya, P. A. (2020). Developing Coursebook Of Food And Beverage Service For Tourism Class In Private Vocational High School At Smks Pgri Tembuku. Stkip Suar Bangli.

Ayuni, N. P., Adiwijaya, P. A., \& Manuaba, I. B. A. L. (2020). Developing Front Office Coursebook For Tourism Class In Private Vocational High School In Bangli. Stkip Suar Bangli.

Basturkmen, H. (2010). Developing Courses In English For Specific Purposes. Palgrave Macmillan.

Dudley-Evans, \& St.John. (2005). English For Specific Purposes Modules In Listening And Speaking For Dentistry Students. The Asian Esp Journal.

Hamidah, F. N., \& Yanuarmawan, D. (2019). Penerapan English For Specific Purposes Untuk Meningkatkan 
1543 Analisa Kebutuhan dalam Pengembangan Bahan Ajar Digital Bahasa Inggris Pariwisata di Sekolah Menengah Kejuruan - Pande Agus Adiwijaya, Luh Made Dwi Wedayanthi

DOI: https://doi.org/10.31004/edukatif.v4i1.1704

Pengajaran Bahasa Inggris Pada Guru Sekolah Menengah Kejuruan. Jurnal Abdinus: Jurnal Pengabdian Nusantara, 2(2), 236. Https://Doi.Org/10.29407/Ja.V2i2.12767

Howard, J., \& Major, J. (2004). Guidelines For Designing Effective English Language Teaching Materials. 9th Conference Of Pan Pacific Association Of ..., 101-109. Http://Www.Paaljapan.Org/Resources/Proceedings/Paal9/Pdf/Howard.Pdf

Indrasari, N. (2016). English For Specific Purposes: A Need Analysis At The Second Semester Of Physics Education Students Of Iain Raden Intan Lampung In The Academic Year Of 2015/2016. English Education: Jurnal Tadris Bahasa Inggris, 9(1), 161-172.

Paltridge, B., \& Starfield, S. (2013). The Handbook Of English For Specific Purposes. Wiley-Blackwell.

Sugiyono. (2009). Metode Penelitian Kuantitatif, Kualitatif Dan R\&D. Alfabeta.

Tomlinson, B. (1998). Materials Development In Language Teaching. Cambridge University Press.

Utami, S., Sakitri, W., Karolina, L., \& Sebayang, B. (2014). Peningkatan Kualitas Sumber Daya Guru. Doaj, $3(1), 125-132$.

Widiana, A., Adiwijaya, P. A., \& Purnami, N. M. A. (2020). Developing Housekeeping Coursebook For Tourism Class At Smk Pgri Tembuku. Stkip Suar Bangli. 